\title{
MIAROLITIC CAVITIES IN RAPAKIVI GRANITE ON HÄSTHOLMEN, LOVIISA, SOUTHEASTERN FINLAND
}

\author{
KRISTIAN LINDQVIST and VELI SUOMINEN
}

\begin{abstract}
LINDQVIST, K. and SUOMINEN, V., 1987: Miarolitic cavities in rapakivi granite on Hästholmen, Loviisa, southeastern Finland. Bull. Geol. Soc. Finland 59, Part 1, 71-75.

Miarolitic cavities are described from drill cores taken from rapakivi granite on Hästholmen, an island about $80 \mathrm{~km}$ east of Helsinki. The distribution of cavities between different textural types of rapakivi seems to favour the equigranular medium to coarse-grained and pyterlitic types. Cavities were found to be concentrated in the upper parts of the type in question. Minerals found in the cavities are: albitic plagioclase, quartz, haematite, pyrite and chlorite. The contents of the cavities differ in the joint fillings and the materials are not genetically related.
\end{abstract}

Key words: plagioclase, quartz, pyrite, hematite, miarolitic, rapakivi, Finland, Loviisa, Hästholmen.

Kristian Lindqvist and Veli Suominen: Geological Survey of Finland, Kivimiehentie 1, SF-02150 Espoo Finland.

\section{Introduction}

Miarolitic cavities are characteristic of the rapakivi granites in southern Finland (Eskola 1927, p. 101). In the present context, the term miarolitic cavity refers to small, vesicular - like cavities with idiomorphic crystals on their walls. However, cavities seen in outcrops are often weathered, and detailed studies of the mineralogy of miarolitic cavities are rare. Vorma (1961) reported the minerals found in miarolitic cavities in pegmatites within the Viipuri (Wiborg) rapakivi area, and Kinnunen et al. (1987) have described miarolitic quartz crystal cavities found near the surface in the same rapakivi area.

Diamond drilling in connection with studies of radioactive waste deposition on Hästhol- men, Loviisa, some $80 \mathrm{~km}$ east of Helsinki, exposed rapakivitic material from depths up to a little more than $200 \mathrm{~m}$. The holes bottomed in the rapakivi. Several miarolitic cavities were observed in the drill cores but special attention was paid to cavities appearing at a depth of 180 $200 \mathrm{~m}$. The size of the cavities throughout the cores varied from $1 \mathrm{~cm}$ up to about $5 \mathrm{~cm}$. The minerals were studied using optical and X-ray diffraction methods.

\section{Geological setting}

The Viipuri rapakivi area has been described by several authors, e.g. Simonen and Vorma (1969) and Vorma (1971). According to the geological map of the area (Laitala 1964, 1965 and 
1984) and the work by Vorma (1971), several different textural types of rapakivi granite can be distinguished. The intrusion of the massif is thought to have proceeded in several phases (ibid.). Vaasjoki (1977) reported the age of the massif to be 1640-1700 Ma.

Hästholmen is situated $7-8 \mathrm{~km}$ to the east of the western contact of the Wiborg rapakivi area. In his study of 11 drill cores from Hästholmen, Suominen (1983) interpreted the different textural types seen as flat lying or very gently dipping thin laccoliths of different intrusion phases, thus imparting a lamellar structure to the massif. The most common rapakivi variety on Hästholmen is pyterlite, but wiborgite and even-grained rapakivi and rapakivi aplite are also met with (for the different textural type descriptions, see Wahl 1925). Occasionally pegmatitic quartz portions were intersected. Joints filled with fluorite were common, and idiomorphic fluorite cubes covered the joint surfaces in some open joints. Miarolitic cavities filled with quartz and hornblende were reported. Modal analyses of the rapakivi varieties in- tersected and the mineral parageneses of the joint fillings have been presented by Suominen (op. cit).

\section{Sampling}

The samples consist of 11 drill cores with a diameter of $51.3 \mathrm{~mm}$ from depths of up to about $200 \mathrm{~m}$. The diamond core drilling was carried out as part of a project studying the feasibility of constructing a repository for low- to intermediate-level radioactive waste. The drill cores were used in different tests for assessing the suitability of the rock formation, joint fillings and fracture zones in the site of a repository. The drilling was carried out with special care in an effort to save even the finest joint material. Hence, not even the weak portions of the rock penetrated by drill underwent crushing and were not reported as core lost. Ion exchanged water was used as coolant during the drilling.

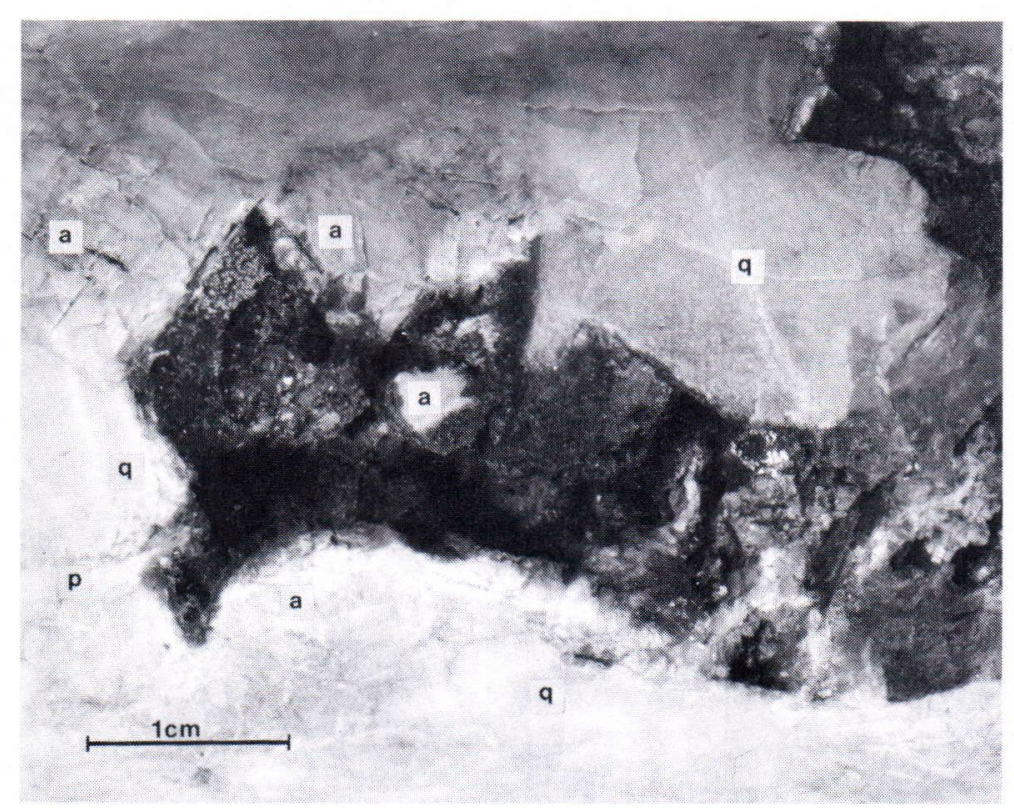

Fig. 1 Miarolitic cavity in drill core Y8, depth 199.86-199.91 m. p = plagioclase, $\mathrm{a}=$ alkali feldspar and $\mathrm{q}=$ quartz. Photograph by E. Halme. 


\section{Miarolitic cavities}

The drill cores were macroscopically studied and the distribution of miarolitic cavities reported. The cavities are usually irregular in shape and the contents vary (see Fig. 1). Some are completely filled, mainly with quartz, others are partly filled with plagioclase and quartz, or are now void with only plagioclase, alkali feldspar and quartz protruding from the walls. The latter type may originally have been large fluid inclusions. Cavities found at greater depths seem to be more void than cavities found near the present surface.

The occurrence of cavities proved to be at least partly controlled by the different rapakivi types. The distribution of cavities was found to favour the pyterlitic and equigranular medium-

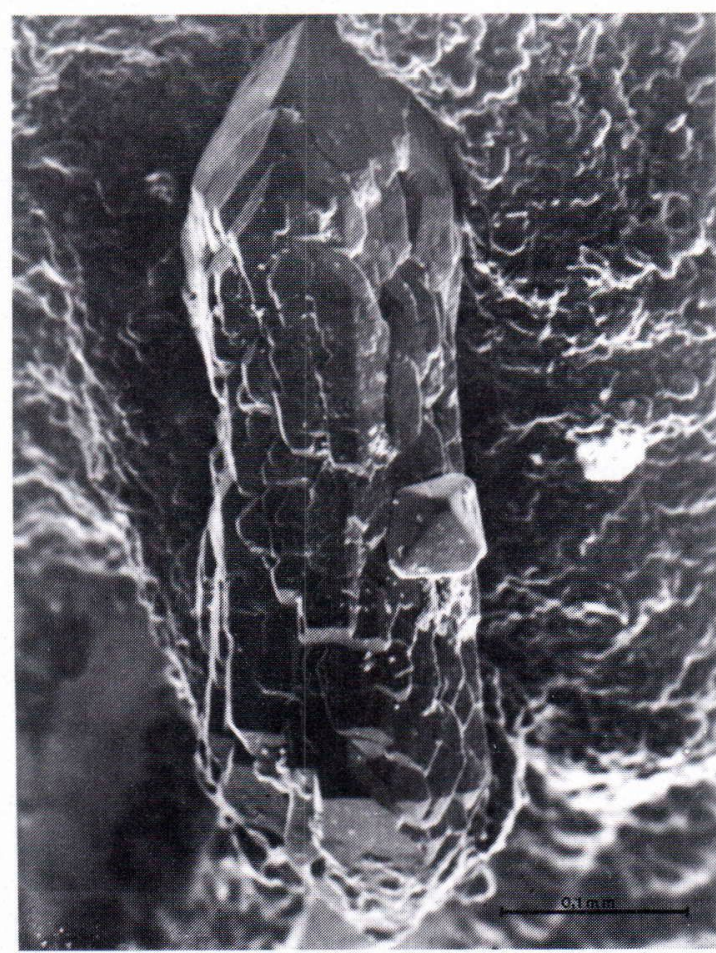

Fig. 2. Growth layers on the surface of a quartz crystal, with a pyrite crystal of a miarolitic cavity of drill core $\mathrm{Y} 8$, depth 199.86-199.91 m.

Scanning electron microphotograph by B. Johanson. to coarse-grained types rather than the wiborgite and rapakivi aplite. Likewise an uneven distribution of cavities was found within the same type of rapakivi granite: cavities were more frequent near the upper contact of the type under consideration.

Two of the partly filled cavities were chosen as representatives of this type of cavity and were submitted to more detailed study. One cavity, with a void area of $2 \times 5 \mathrm{~cm}^{2}$, occurred at a depth of 199.86-199.91 m, the other with an opening of $1 \times 2 \mathrm{~cm}^{2}$ at a depth of $180.86-180.88 \mathrm{~m}$. The most abundant mineral in the cavities is albitic plagioclase. It was the first mineral to crystallize within the cavities and occurs as colourless, short-prismatic euhedral crystals, $1-2 \mathrm{~mm}$ in length. Later crystallization products are euhedral quartz and globular haematite, often on the plagioclase crystals. The quartz crystals are colourless prisms, shorter than $0.5 \mathrm{~mm}$, terminated by rhombohedra. The crystals show growth layers (see Fig. 2.).

Under the microscope, the crystals were found to contain both fluid and mineral inclusions and it is thought that these may be the cause of the growth layers (cf. Grigor'ev 1965 , p. 86). No distortion of the crystal form was established although this has been reported to occur during the growth of quartz crystals (op. cit. p. 77). Alkali feldspars in the miarolitic cavities are maximum microcline, as is the alkali feldspar in pegmatites near the miarolitic cavities (see Table 1.). Haematite occurs as metallic, reddish or black globules with a diameter of less than $0.5 \mathrm{~mm}$ (Fig. 3.). As the last crystallization product, euhedral pyrite was

Table 1. Triclinity indices (according to Goldsmith and Laves 1954) of alkali feldspar in rapakivi samples from drill core Y8, Hästholmen, Loviisa.

\begin{tabular}{ll}
\hline Sample No & index \\
\hline Y8 117.73-117.96 & 0.94 (pegmatite) \\
Y8 180.77-181.12 & 0.88 (miarolitic cavity) \\
Y8 199.86-200.25 & 0.94 (miarolitic pegmatite) \\
\hline
\end{tabular}




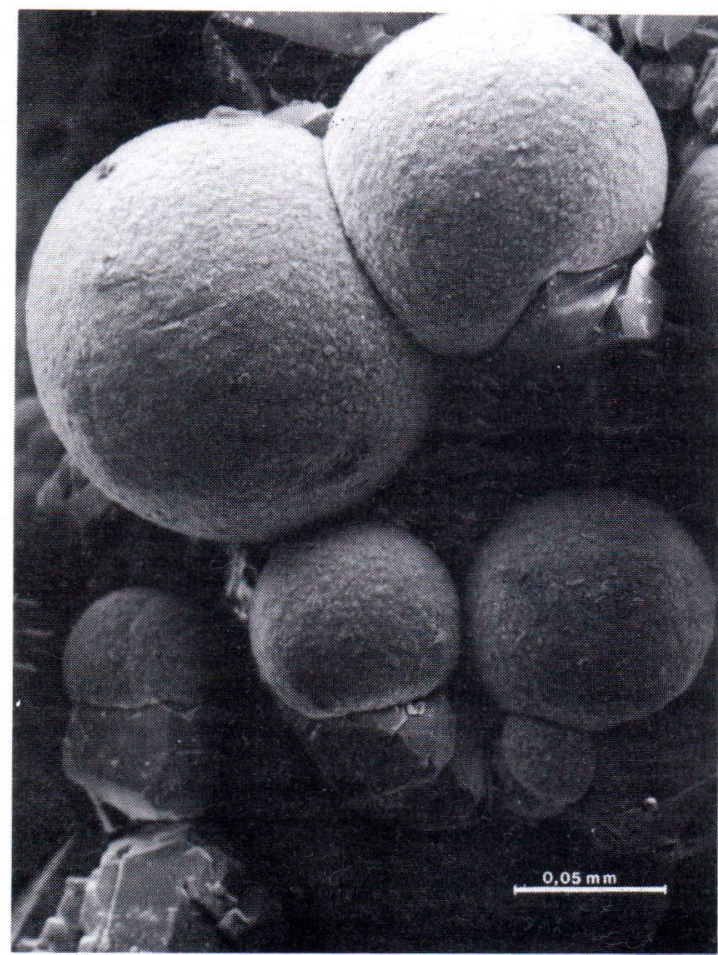

Fig. 3. Haematite globules, partly crystallized on quartz of a miarolitic cavity of drill core Y8, depth 199.86-99.91 m. Scanning electron microphotograph by B. Johanson.

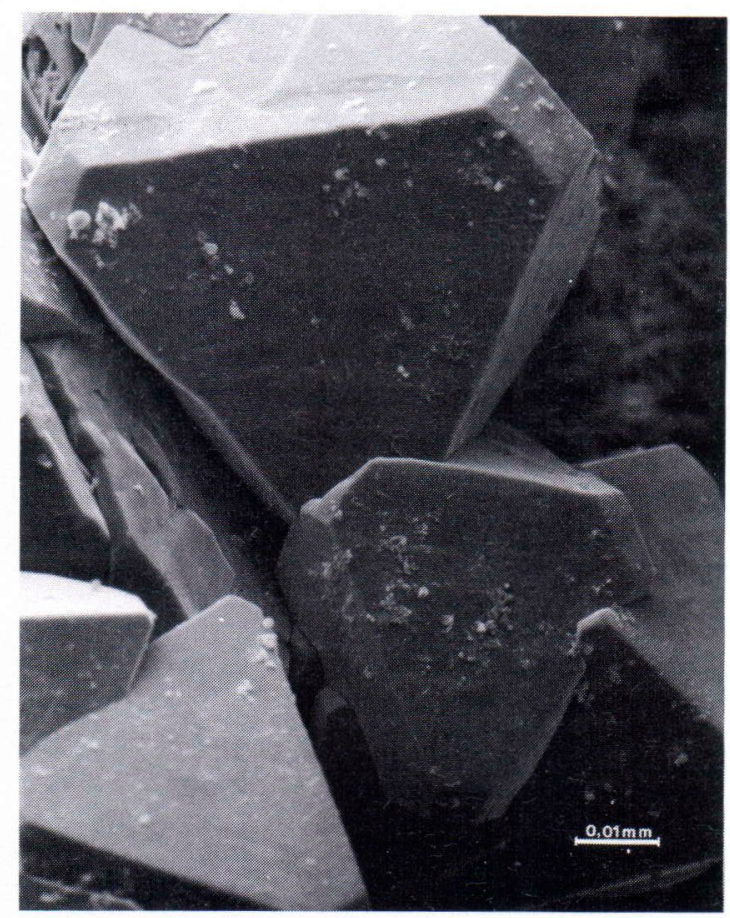

Fig. 4. Euhedral pyrite crystals with (100) and (111) of a miarolitic cavity of drill core Y8, depth $180.86-180.88 \mathrm{~m}$. Scanning electron microphotograph by B. Johanson.

tural types seen represent different intrusion phases. The distribution of miarolitic cavities seems to favour equigranular medium- to coarse-grained and pyterlitic types rather than wiborgite and aplitic types. The distribution pattern could be well understood if the different textural types represented different intrusive phases, because the amount of residual volatile-rich liquids varies between the different intrusive phases (Vorma 1971). According to Buckley (1974), the most widely accepted theory of formation of miarolitic cavities holds that these result from volatiles in the magma during the late formation of an igneous body. These volatiles form bubbles and, as a result of immiscibility, cavities are created during the cooling phase. Furthermore, the large number of cavities in the upper part of the intrusive phase in textural types of rapakivi granite had been intersected. According to Suominen (1983), the tex- 
question is thought to indicate the difference in density between bubbles and the surrounding material. Being lighter than the surrounding melt, bubbles tend to rise towards the surface. The concentration of cavities in the upper part of the intrusive phase supports this concept. The difference in the contents of the cavities is attributed to later processes. Cavities that are completely, or almost completely, void, have remainded practically intact since their formation, whereas cavities with more material, above all quartz, have been filled with hydrothermal fluids. Pegmatitic quartz portions found in the drill cores most likely represent primary miarolitic cavities completely filled later. This genetic hypothesis is consistent with the observations by Vorma (1961) of pegmatites in rapakivi granite and their occurrence near Langinkoski. The main mineral in cavities that has not been involved in hydrothermal processes is albitic plagioclase, whereas quartz is

\section{References}

Buckley, B. W., 1974. Miarolitic minerals of the Conway granite. Rocks Miner. 49, 164-166.

Eskola, P., 1927. Petrographische Charakteristik der kristallinen Gesteine von Finnland. Fortschr. Mineral. Kristallogr. Petrogr. 11, 57-112.

Goldsmith, J. R. \& Laves, F., 1954. The microcline-sanidine stability relations. Geochim. Cosmochim. Acta 5, $1-19$.

Grigor'ev, D. P., 1965. Ontogeny of minerals. Israel Program for Scientific Translations, Jerusalem., 250 p.

Kinnunen, K., Lindqvist, K. \& Lahtinen, R. 1987. Fluid history from crystal cavities in rapakivi, Pyterlahti, southeastern Finland. Bull. Geol. Soc. Finland. 59, $35-44$.

Laitala, M., 1964. Pre-Quaternary rocks, sheet 3021, Porvoo, Geological map of Finland 1:100.000.

-; 1965. Pre-Quaternary rocks, sheet 3012, Pellinki. Geological map of Finland 1:100.000.

-; 1984. Pellingin ja Porvoon kartta-alueiden kallioperä. Summary: Pre-Quaternary rocks of the Pellinki and Porvoo map-sheet areas. Explanation to the maps., 53 p. the main constituent in cavities affected by hydrothermal liquids. The role of hydrothermal fluids and crystallization temperatures in miarolitic cavities has been discussed by Kinnunen et al. (1987).

Several joints were seen in the immediate vicinity of the miarolitic cavities. The mineral parageneses of the joint fillings reported by Suominen (1983) differ from those of the miarolitic cavities, and thus the joints and cavities represent different evolution paths.

Acknowledgements Imatran Voima Co kindly permitted us to use the drill cores for our study, which is highly appreciated. The authors also thank Professor Atso Vorma for critically reading the manuscript, Mrs. Mirja Saarinen for assisting with the X-ray studies, the late Erkki Halme for the photograph and Bo Johanson for the SEM photos. Thanks are also due to our referee, Dr Kari Kinnunen, for his comments, wich improved the manuscript, and to Mrs Gillian Häkli for checking and correcting the English of our draft.

Simonen, A. \& Vorma, A., 1969. Amphibole and biotite from rapakivi. Bull. Comm. Géol. Finlande 238, 28 p.

Suominen, V., 1983. Loviisan Hästholmenin geologinen rakenne: yhteenveto kallionäytekairauksien Y1-Y11 kallioperägeologisista tutkimuksista. Summary: Petrography of the rapakivi granites and joint filling minerals in drill cores in Hästholmen, Loviisa. Voimayhtiöiden ydinjätetoimikunta - Nuclear Waste Commission of Finnish Power Companies. Report YJT-83-03. 25 p. +47 p. appendices.

Wahl, W., 1925. Die Gesteine des Wiborger Rapakiwigebietes. Fennia 45 (20), 127 p.

Vaasjoki, M., 1977. Rapakivi granites and other postorogenic rocks in Finland: their age and the lead isotopic composition of certain associated galena mineralizations. Geol. Surv. Finland, Bull. 294, 64 p.

Vorma, A., 1961. A new apophyllite occurrence in the Viipuri rapakivi area. Compt. R. Soc. Géol. Finlande 33, 399-404.

-; 1971. Alkali feldspars of the Wiborg rapakivi massif in southeastern Finland. Bull. Comm. Géol. Finlande 246, 72 p.

Manuscript received May 27, 1985 